\title{
The Performance of Florida Medicaid Health Plans on Follow-Up after Hospitalization for Mental Illness in 2014
}

\author{
Edmund R Becker ${ }^{2 *}$, Matlin Gilman ${ }^{1}$, Marie Mc Pherson ${ }^{3}$, Beom Lee $^{3}$ and Sabrina Singh ${ }^{3}$ \\ ${ }^{1}$ Health Policy Analyst, United Hospital Fund, USA \\ ${ }^{2}$ Professor of Health Policy and Management, Rollins School of Public Health at Emory University, USA \\ ${ }^{3}$ Florida Medicaid Drug Therapy Management Program for Behavioral Health, College of Behavioral \& Community Services, University of South Florida, \\ USA
}

Submission: January 09, 2018; Published: February 27, 2018

*Corresponding author: Edmund R Becker, Professor of Health Policy and Management, Rollins School of Public Health at Emory University, USA, Tel: 404-727-9969; Email: ebeck01@emory.edu

Abstract

Objective: Our primary objective was to examine whether Florida Medicaid health plans are successful in ensuring that timely follow-up is provided after hospitalizations for mental illness. Our secondary objective was to assess the extent to which there is a relationship between plans' performance and mental health provider network size.

Methods: We used 2008-2014 HEDIS data to compare each Florida Medicaid health plan's rates of 7-day and 30-day follow-up after hospitalization for mental illness with the rates among all Medicaid HMOs nationwide. Rates for the Florida Medicaid health plans were posted as reported and certified by the plans to Florida's Agency for Health Care Administration (AHCA).

Results: Florida Medicaid health plans' average rate of 7-day follow-up after hospitalization for mental illness in 2014 was just 25 percent - 19 percentage points lower than the national average (44 percent) and just four percentage points higher than the national decile (21 percent) among Medicaid HMOs. Similarly, their average rate of 30-day follow-up was just 38 percent - 25 percentage points lower than the national average (63 percent) and one percentage point lower than the national decile (39 percent) among Medicaid HMOs. Their rates have been lower than the national average among Medicaid HMOs since 2008 (the earliest year for which data was available).

Conclusion: The performance of Florida Medicaid health plans on follow-up after hospitalization for mental illness is poor and has been for years. The plans' poor follow-up performance is likely adversely affecting the health of their already vulnerable members who have been hospitalized for mental illness.

Keywords: Mental health hospitalization outcomes; Florida managed care program performance; Health Care Utilization Project (HCUP)

Abbreviations: AHCA: Agency for Health Care Administration; HCUP: Health Care Utilization Project; SMMC: Statewide Medicaid Managed Care; NCQA: National Committee for Quality Assurance

\section{Introduction}

States are increasingly turning to Medicaid managed care as a strategy to contain expenditures and improve care for beneficiaries [1]. More than half the states have increased their reliance on Medicaid managed care in recent years by making managed care health plans available to new populations and new geographic areas within their state [2]. And a smaller number of states, including Florida, have gone further and made enrollment in health plans mandatory for most beneficiaries in the state [3]. Florida's Statewide Medicaid Managed Care (SMMC) reform, the reform making enrollment in health plans mandatory for the vast majority of beneficiaries statewide, was completed in 2014. According to Florida's Agency for Health Care Administration (AHCA), the agency that oversees the state's Medicaid program, the SMMC reform has been largely successful in providing high quality care to beneficiaries at lower costs to the state [4]. A January 2016 AHCA report, for example, shows that annual spending per beneficiary has trended downward since the SMMC reform was implemented and that beneficiaries tend to be highly satisfied with their health plans [5].

Yet, while spending may be trending downward and overall satisfaction may be high, there is concern over the quality of health care being provided to the Florida Medicaid population 
with serious mental health conditions. A recent study, for example, found that Medicaid beneficiaries in the state who are hospitalized for a mental illness are often readmitted to a hospital within 30 days, which may indicate that inadequate follow-up care is being provided [6]. There is an extensive body of literature that shows that timely follow-up after hospitalization for mental illness is critical for the patient's wellbeing [7]. Therefore, this study presents data on Florida Medicaid health plans' performance on follow-up after hospitalization for mental illness relative to all Medicaid HMOs nationwide. It also seeks to examine whether Florida Medicaid plans with larger mental health provider networks perform better on this quality metric than plans with smaller provider networks.

\section{Methods}

In Table 1 we list each Florida Medicaid plan currently operating and present plan characteristics, including whether the plan is a standard or specialty plan, its overall enrollment size, its share of hospitalizations for mental illness among all plans statewide, its operating margins, its mental health provider network size, its ownership status, and its regions of operation (which correspond to Florida counties). The data for this table come from AHCA. In Figure 1 we compare Florida Medicaid plans' rates of 7-day and 30-day follow-up after hospitalization to the national average and national bottom decile rates among Medicaid HMOs in 2014, and in Figure 2 we trace those statewide and national average rates annually back to 2008. We obtained the rates for Florida Medicaid plans from AHCA, and we obtained the rates for Medicaid HMOs nationwide from the National Committee for Quality Assurance (NCQA). NCQA is a non-profit organization that develops the HEDIS quality measures that ACHA uses to identify opportunities for improvement, including the follow-up measures used in this study (Figure 3).

NCQA defines follow-up after hospitalization for mental illness as "the percentage of discharges for members 6 years of age and older who were hospitalized for treatment of selected mental health disorders and who had an outpatient visit, an intensive outpatient encounter or partial hospitalization with a mental health practitioner" [8].

Two rates are reported

a) The percentage of members who received follow-up within 7 days of discharge, and

b) The percentage of members who received follow-up within 30 days of discharge. As mentioned previously, timely follow-up is critical to ensuring positive outcomes for the patient [9].

Table 1: Characteristics of Florida Medicaid Health Plans, 2014.

\begin{tabular}{|c|c|c|c|c|c|c|c|c|c|c|c|}
\hline \multirow[t]{2}{*}{ Plan } & \multirow[t]{2}{*}{ Specialty } & \multicolumn{4}{|c|}{ Satisfaction } & \multirow{2}{*}{$\begin{array}{c}\begin{array}{c}\text { Enroll } \\
\text { ment }\end{array} \\
\\
\\
\\
\% \\
\text { of enro } \\
\text { llees }\end{array}$} & \multirow[b]{2}{*}{$\begin{array}{c}\text { MH stays } \\
\\
\text { \% of } \\
\text { mental } \\
\text { health } \\
\text { hospital } \\
\text { admis } \\
\text { sions }\end{array}$} & \multirow[b]{2}{*}{$\begin{array}{c}\text { Margins } \\
\\
\text { oper } \\
\text { ating } \\
\text { ma } \\
\text { rgins }\end{array}$} & \multirow[b]{2}{*}{$\begin{array}{c}\text { Network } \\
\\
\text { Size } \\
\text { of } \\
\text { network } \\
\text { (e.g., \# of } \\
\text { psychia } \\
\text { trists per } \\
\text { 1,000 } \\
\text { mem } \\
\text { bers) }\end{array}$} & \multirow{2}{*}{$\begin{array}{c}\text { Owner } \\
\text { ship }\end{array}$} & \multirow[b]{2}{*}{$\begin{array}{c}\text { Regions } \\
\\
\text { Regi } \\
\text { ons } \\
\text { of } \\
\text { ope } \\
\text { ration }\end{array}$} \\
\hline & & $\begin{array}{c}\% \text { of } \\
\text { adults } \\
\text { rating } \\
8,9 \text { or } \\
10\end{array}$ & $\begin{array}{l}\% \text { of } \\
\text { adults } \\
\text { repor } \\
\text { ting } \\
\text { usually } \\
\text { or } \\
\text { always } \\
\text { easy } \\
\text { to get } \\
\text { needed } \\
\text { care }\end{array}$ & $\begin{array}{l}\% \text { of } \\
\text { adults } \\
\text { repor } \\
\text { ting } \\
\text { usually } \\
\text { or } \\
\text { always } \\
\text { easy } \\
\text { to get } \\
\text { care } \\
\text { quickly }\end{array}$ & $\begin{array}{l}\text { \% of } \\
\text { adults } \\
\text { repor } \\
\text { ting } \\
\text { doctors } \\
\text { usua } \\
\text { lly } \\
\text { or } \\
\text { always } \\
\text { commun } \\
\text { icate } \\
\text { well }\end{array}$ & & & & & & \\
\hline $\begin{array}{l}\text { Ameri } \\
\text { group }\end{array}$ & $\begin{array}{c}\text { Non- } \\
\text { specialty }\end{array}$ & 77 & 82 & 80 & 89 & 11 & 9.5 & -2.9 & $?$ & $\begin{array}{l}\text { For- } \\
\text { profit }\end{array}$ & $5-7,11$ \\
\hline $\begin{array}{l}\text { Better } \\
\text { Health }\end{array}$ & $\begin{array}{c}\text { Non- } \\
\text { specialty }\end{array}$ & 75 & 78 & 84 & 93 & 3 & 3.8 & 0.3 & $?$ & $\begin{array}{l}\text { For- } \\
\text { profit }\end{array}$ & 6,10 \\
\hline CMS & Children & - & - & - & - & 2 & 0.4 & - & $?$ & $\begin{array}{c}\text { Govern } \\
\text { ment }\end{array}$ & $1-11$ \\
\hline $\mathrm{CHA}$ & HIV/AIDS & 77 & 83 & 87 & 95 & 0 & 2.3 & 4.2 & $?$ & $\begin{array}{c}\text { For- } \\
\text { profit }\end{array}$ & $1-3,5-11$ \\
\hline Coventry & $\begin{array}{c}\text { Non- } \\
\text { specialty }\end{array}$ & 73 & 76 & 79 & 89 & 2 & 1.0 & -6.8 & $?$ & $\begin{array}{l}\text { For- } \\
\text { profit }\end{array}$ & 11 \\
\hline Humana & $\begin{array}{c}\text { Non- } \\
\text { specialty }\end{array}$ & 74 & 73 & 78 & 89 & 11 & 18.1 & -1.4 & $?$ & $\begin{array}{c}\text { For- } \\
\text { profit }\end{array}$ & $1,6,9-11$ \\
\hline Magellan & $\begin{array}{l}\text { Mental } \\
\text { Illness }\end{array}$ & 64 & - & - & 78 & 1 & 15.4 & -7.0 & $?$ & $\begin{array}{l}\text { For- } \\
\text { profit }\end{array}$ & $2,4-7,9-11$ \\
\hline Molina & $\begin{array}{c}\text { Non- } \\
\text { specialty }\end{array}$ & 72 & 80 & 80 & 91 & 10 & 3.1 & -8.6 & $?$ & $\begin{array}{l}\text { For- } \\
\text { profit }\end{array}$ & $1,4,6-9,11$ \\
\hline
\end{tabular}




\begin{tabular}{|c|c|c|c|c|c|c|c|c|c|c|c|}
\hline Positive & HIV/AIDS & 78 & 84 & 85 & 95 & 0 & 0.4 & -6.3 & $?$ & $\begin{array}{l}\text { Non- } \\
\text { profit }\end{array}$ & $10-11$ \\
\hline Prestige & $\begin{array}{c}\text { Non- } \\
\text { specialty }\end{array}$ & 69 & 81 & 79 & 93 & 10 & 0.9 & -4.5 & $?$ & $\begin{array}{l}\text { For- } \\
\text { profit }\end{array}$ & $2-3,5-9,11$ \\
\hline SFCCN & $\begin{array}{c}\text { Non- } \\
\text { specialty }\end{array}$ & 74 & - & - & 94 & 1 & 0.9 & -1.8 & $?$ & $\begin{array}{l}\text { Non- } \\
\text { profit }\end{array}$ & 10 \\
\hline Simply & $\begin{array}{c}\text { Non- } \\
\text { specialty }\end{array}$ & 88 & 90 & 87 & 98 & 3 & 4.8 & 1.7 & $?$ & $\begin{array}{l}\text { For- } \\
\text { profit }\end{array}$ & 11 \\
\hline Stay well & $\begin{array}{c}\text { Non- } \\
\text { specialty }\end{array}$ & 69 & 80 & 79 & 88 & 23 & 20.3 & -3.9 & $?$ & $\begin{array}{l}\text { For- } \\
\text { profit }\end{array}$ & $2-8,11$ \\
\hline $\begin{array}{l}\text { Sunshine } \\
\text { CW }\end{array}$ & Children & - & - & - & - & - & 0.4 & - & $?$ & $\begin{array}{l}\text { For- } \\
\text { profit }\end{array}$ & $1-11$ \\
\hline $\begin{array}{c}\text { Sun } \\
\text { shine* }\end{array}$ & $\begin{array}{c}\text { Non- } \\
\text { specialty }\end{array}$ & 72 & 84 & 83 & 90 & 14 & 9.2 & -10.7 & $?$ & $\begin{array}{l}\text { For- } \\
\text { profit }\end{array}$ & $3-11$ \\
\hline United & $\begin{array}{c}\text { Non- } \\
\text { specialty }\end{array}$ & 71 & 80 & 83 & 93 & 9 & 9.5 & -24.4 & $?$ & $\begin{array}{l}\text { For- } \\
\text { profit }\end{array}$ & $3-4,7,11$ \\
\hline $\begin{array}{c}\text { Average/ } \\
\text { Total }\end{array}$ & - & 74 & 82 & 83 & 92 & 100 & 100 & -6.4 & $?$ & - & - \\
\hline
\end{tabular}

Source: The member satisfaction results shown are posted as reported and certified by health plans to the Agency for Health Care Administration (AHCA). The enrollment data come from the Florida Office of Insurance Regulation and are current as of December 01, 2014. The specialty, financial, ownership, and region data come from AHCA.

Notes:

Region 1=Escambia, Okaloosa, Santa Rosa, Walton

Region 2=Bay, Calhoun, Franklin, Gadsden, Gulf, Holmes, Jackson, Jefferson, Leon, Liberty, Madison, Taylor, Wakulla, Washington

Region 3=Alachua, Bradford, Citrus, Columbia, Dixie, Gilchrist, Hamilton, Hernando, Lafayette, Lake, Levy, Marion, Putnam, Sumter, Suwannee, Union

Region 4=Baker, Clay, Duval, Flagler, Nassau, St. Johns, Volusia

Region 5=Pasco, Pinellas

Region 6=Hardee, Highlands, Hillsborough, Manatee, Polk

Region 7=Brevard, Orange, Osceola, Seminole

Region 8=Charlotte, Collier, De Soto, Glades, Hendry, Lee, Sarasota

Region 9=Indian River, Martin, Okeechobee, Palm Beach, St. Lucie

Region 10=Broward

Region 11=Miami-Dade, Monroe

\section{Results}

There are 16 Medicaid health plans currently operating in Florida (Table 1). Most (11) are standard (non-specialty) plans, and together they account for the vast majority ( 97 percent) of plan enrollees. There is one specialty plan - Magellan - that only serves those with mental illness. This plan, despite accounting for just 1 percent of plan enrollees, accounts for 15.4 percent of hospitalizations for mental illness statewide. Overall plan satisfaction is reasonable. About three-fourths (74 percent) of adults plan members rate their plan a score of 8,9 , or 10 (with 10 being the highest level of satisfaction). More than four out of five (82 and 83 percent, respectively) report usually or always being able to get needed care and being able to get care quickly. And more than nine out of ten (92 percent) report their doctors usually or always communicate well. Plans' operating margins, by contrast, are very low. The average operating margin among the 15 plans reporting financial data is -6.4 percent. Six plans

have margins below -5 percent - and Magellan is one of them (-7 percent). And only three (small) plans have positive margins. Even so, most of the plans (13 out of 16) are for-profit, and together these for-profit plans account for the vast majority (97 percent) of plan enrollees.

Plans' performance on 7-day follow-up after hospitalization for mental illness is poor (Figure 1). Their average rate of such follow-up is 25 percent - 19 percentage points lower than the national average (44 percent) and just four percentage points higher than the national decile (21 percent) among Medicaid HMOs. Most plans have rates below the national decile. Nearly all have rates below than the national average. The two plans with rates above the national average together account for just 1 percent of hospitalizations for mental illness statewide. Plans' performance on 30-day follow-up is worse. Their average rate is 38 percent - 25 percentage points lower than the national average (63 percent) and one percentage point 
lower than the national decile (39 percent) among Medicaid HMOs. Most plans have rates below the national decile. All of the plans have rates below the national average. Among the three plans with the most hospitalizations for mental illness (together accounting for over half of such hospitalizations statewide), the average rate is 34 percent - 5 percentage points below the national decile. Surprisingly, even the mental health specialty plan Magellan performs very poorly on follow-up after hospitalization for mental illness. Its rate of 7-day follow-up is 16 percent - 9 percentage points below the statewide average and 5 percentage points below the national decile. Similarly, its rate of 30-day follow-up is 30 percent - 8 percentage points below the statewide average and 9 percentage points below the national decile. Furthermore, plans have been performing poorly on follow-up after hospitalization for mental illness for years (Figure 2). In every year since 2008 (the earliest year for which data was available), they have had lower 7-day and 30day follow-up rates than the national average among Medicaid HMOs. In every year since 2009, their rates have been lower than the national average by at least 10 percentage points. And since 2011, their rates have been trending downward.
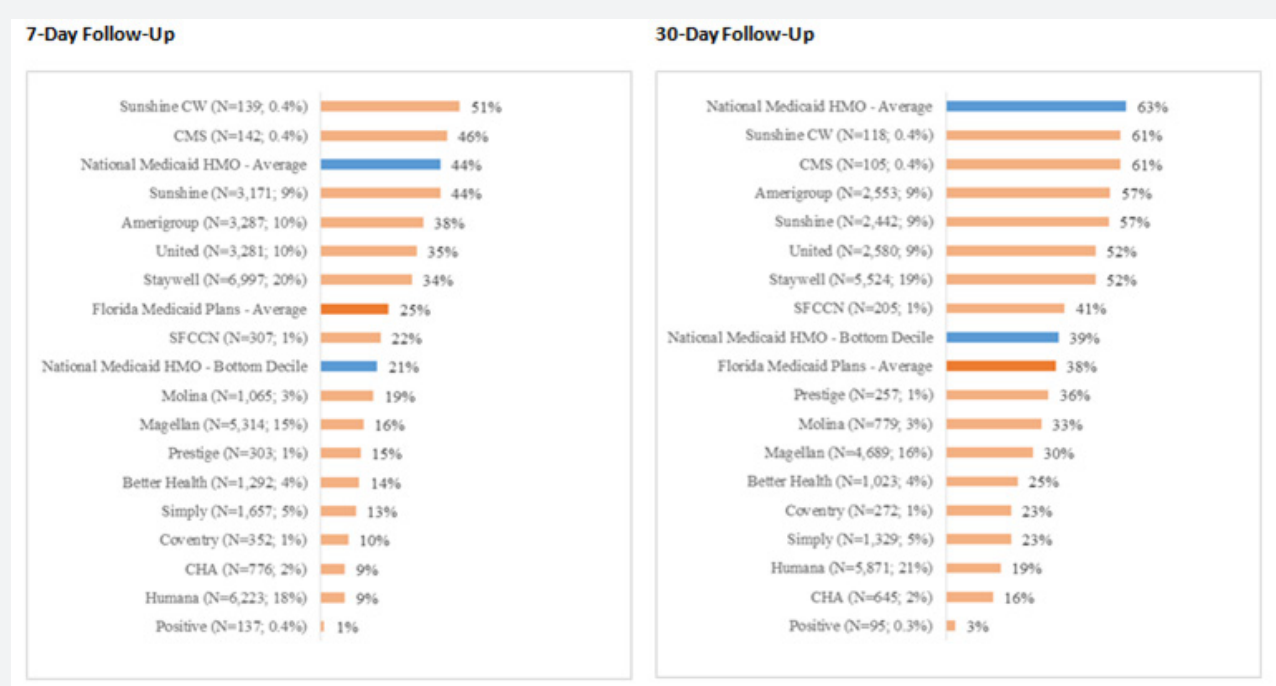

Figure 1: Florida Medicaid Health Plans' Rates on 7-Day and 30-Day Follow-Up after Hospitalization for Mental Illness Compared to All Medicaid HMOs Nationwide, 2014.

Source: The results shown are posted as reported and certified by health plans to the Agency for Health Care Administration (AHCA).

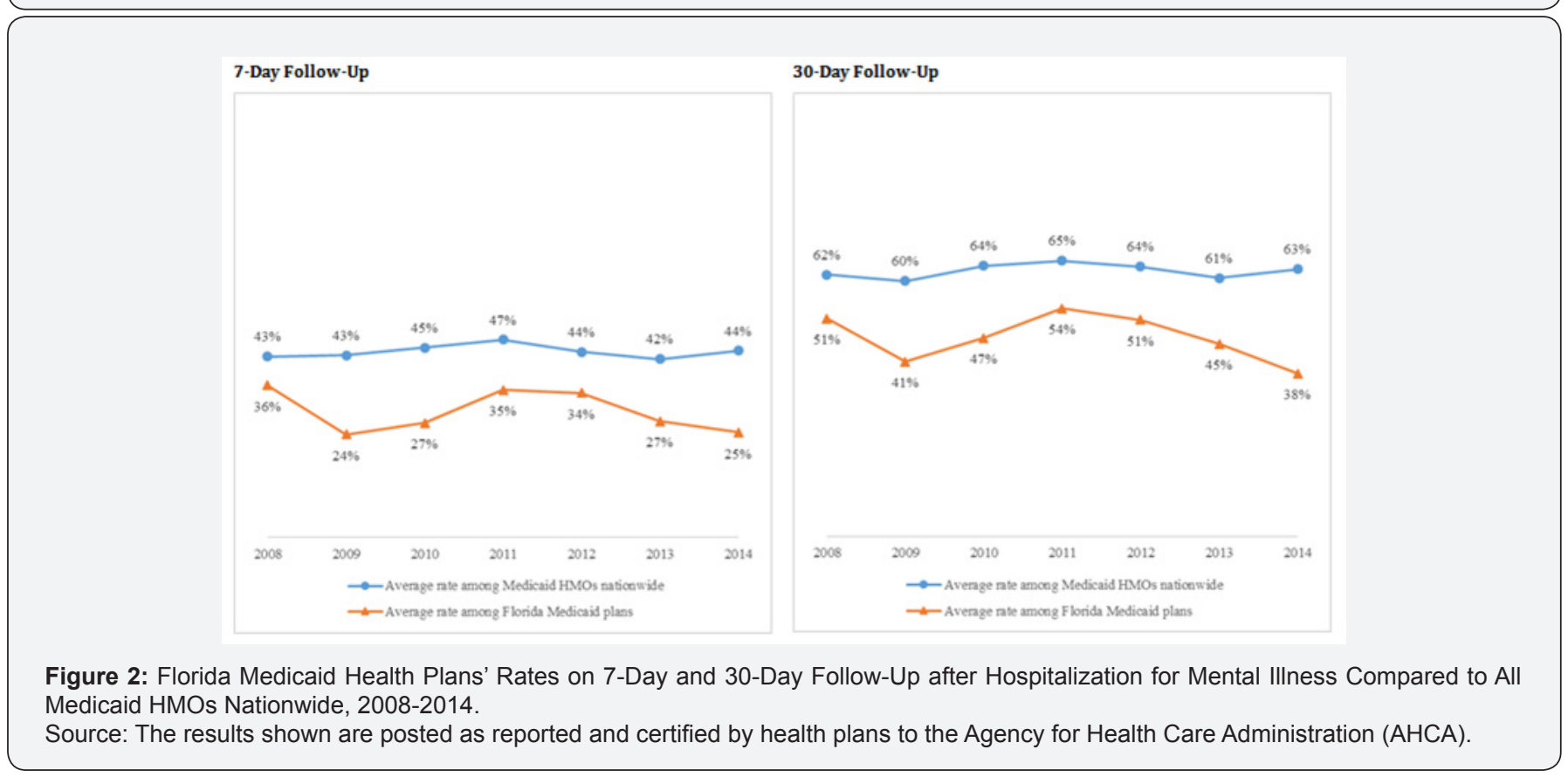




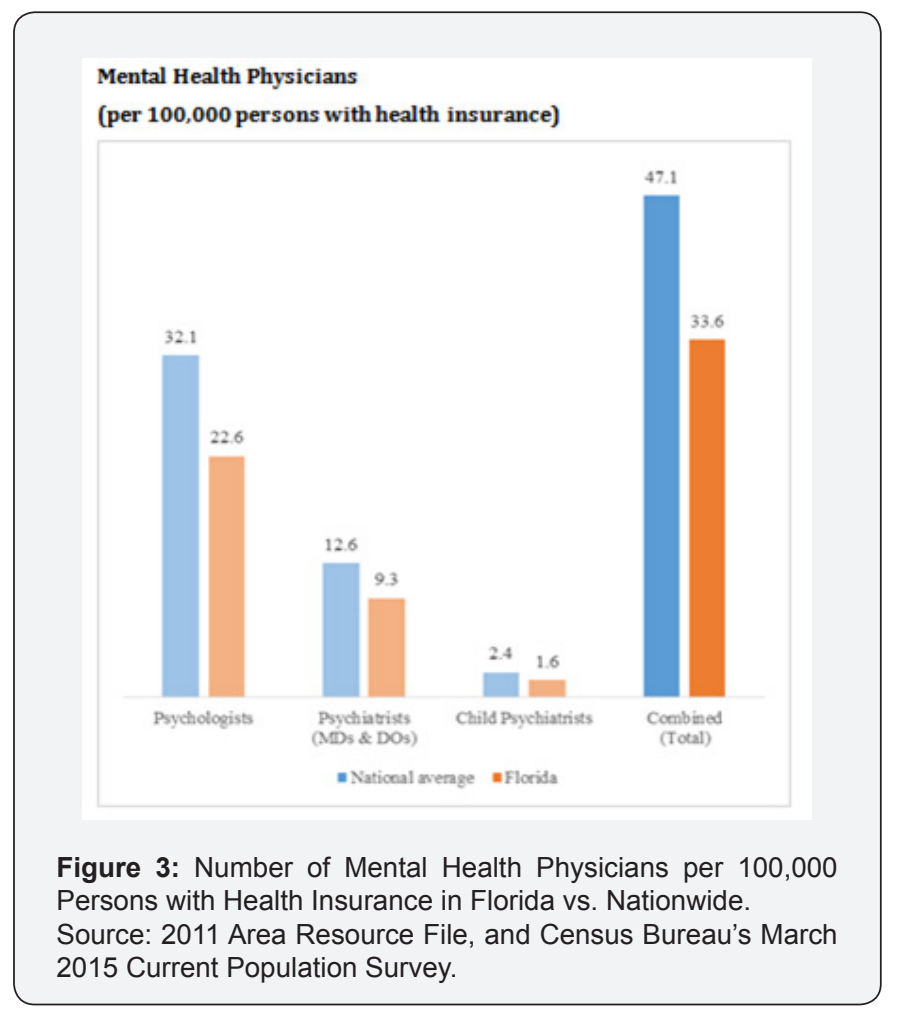

\section{Discussion}

Our study has three main findings. First, Florida Medicaid plans' performance on follow-up after hospitalization for mental illness in the first year of the SMMC reform was very poor. Second, their performance has been poor for many years prior to the SMMC reform as well. Third, it appears there is a poor relationship between the performance of a plan and its mental health provider network size. Taken together, these findings indicate that Medicaid beneficiaries with serious mental health conditions throughout Florida are at risk of not receiving critical health services.

Providing follow-up after hospitalization for mental illness can be difficult, especially in the case of Medicaid hospitalizations. One challenge is that there are not always enough mental health providers available to provide it [10]. According to the Health Resources and Services Administration, many geographic areas around the country and in Florida face a shortage of mental health providers [11]. And studies have shown that many specialist physicians around the country - but especially in Florida and certain other states - are unwilling to treat new Medicaid patients due to low reimbursement rates [12]. Another important challenge is that patients are not always motivated to adhere to their provider's recommendation to receive timely follow-up [13]. Faced with perceived stigma of mental illness and the negative perceptions about treatment, for example, a patient may chose not to comply with treatment. With Medicaid patients, the issue of motivation is exacerbated by the issue of low socioeconomic status. The fact that they are poor means they have fewer resources and are faced with other pressing issues. It also means the cost or availability of transportation may be decisive factors.

Nevertheless, timely and regular follow-up after hospitalization for mental illness is essential [14]. Such followup with a mental health practitioner helps to ensure that the patient's transition out of the hospital is supported and that the progress made during the hospital stay continues [15]. It also helps practitioners detect early post-hospitalization health or medication problems and provide critical care, like regular assessments and documentation of the patient's response to all treatments [16]. Patients with serious mental illnesses who do not receive follow-up are at risk of having a relapse in health and being readmitted to a hospital [17]. One of the intentions of Florida's SMMC reform has been to help Medicaid beneficiaries receive timely follow-up after hospitalization for mental illness. To this end, it establishes regional minimum required mental health provider ratios for Medicaid health plans and travel time standards. Standard plans are required to have in each region a minimum of one adult psychiatrist per 1,500 enrollees and one child psychiatrist per 7,100 enrollees, and the seriousmental-illness specialty plan Magellan is required to have a minimum of one adult psychiatrist per 375 enrollees and one child psychiatrist per 3,500 enrollees [18]. Standard plans are required to ensure that at least 85 or 90 percent of the required specialists in their network, depending on region, are accepting new Medicaid patients [19]. And the travel time for enrollees in urban counties to see a psychiatrist must not exceed 30 minutes whereas, and the travel time for enrollees in rural counties to see a psychiatrist must not exceed 60 minutes [20].

In addition, the reform allows AHCA to sanction Medicaid plans for failure to achieve minimum scores on 7-day followup after hospitalization for mental illness and other mentalhealth HEDIS performance measures. After the first year of poor performance, plans may be required to complete a Performance Measure Action Plan and submit it to AHCA [21]. They may also receive a monetary sanction of up to $\$ 10,000$ and liquated damages of up to $\$ 3.50$ per member. However, our study found that, despite the reform's intentions, Florida Medicaid plans' performance on timely follow-up after hospitalization is at an all-time low [22]. Thus, to date, the reform's regional minimum required mental health provider ratios, travel time standards, and threats of monetary sanctions appear to have done nothing to reverse Florida's longstanding history of failing its beneficiaries who have been hospitalized for mental illness. Our study has limitations. For one, it examines plans' performance through 2014, the first year of the SMMC reform [23]. Ideally, we would have liked to have also examined plans' performance through 2015; but data for that year was not yet available at the time of our study. Second, our study does not control for patient characteristics that could have potentially affected likelihood of receiving follow-up. Still, we believe our approach to evaluating plans' follow-up performance - which is the same approach that NCQA uses - is sound without such adjustments. 


\section{Conclusion}

While members of Florida Medicaid plans may be generally satisfied with their plans, the plans are performing poorly on follow-up after hospitalization for mental illness and have been performing poorly on this quality metric for years. Their poor follow-up performance is likely adversely affecting the health of their already vulnerable members who have been hospitalized for mental illness. Going forward, it is important to continue monitoring Florida's performance on follow-up after Medicaid hospitalizations for mental illness. Given that reasonable plan satisfaction scores do not always translate to reasonable rates of follow-up, as more states throughout the nation increase their reliance on Medicaid managed care, it will also be important to make sure that evaluations of the managed care programs in those states give special attention to the quality of mental health care as well.

\section{References}

1. L Summer, J Hoadley (2014) The Role of Medicaid Managed Care in Health Delivery System Innovation. The Common wealth Fund, USA.

2. VK Smith, K Gifford, E Ellis, R Rudowitz, L Snyder, et al. (2015) Medicaid Reforms to Expand Coverage, Control Costs and Improve Care: Results from a 50-State Medicaid Budget Survey for State Fiscal Years 2015 and 2016. Kaiser Family Foundation, California, USA.

3. J Paradise (2014) Key Findings on Medicaid Managed Care: Highlights from the Medicaid Managed Care Market Tracker. Kaiser Family Foundation, California, USA.

4. LM Beitsch (2017) Independent Assessment of the Florida Statewide Medicaid Managed Care Long-term Care Program. Final Interim Report (FY2014-15).

5. JM Senior (2016) Florida Medicaid: Statewide Medicaid Managed Care. Florida's Agency for Health Care Administration, USA.

6. AB Busch, AM Epstein, TG Mc Guire, ST Normand, RG Frank (2015) Thirty Day Hospital Readmission for Medicaid Enrollees with Schizophrenia: The Role of Local Health Care Systems. J Ment Health Policy Econ 18(3): 115-124.

7. (2014) National Quality Measures Clearinghouse. Measure Summary: 7-Day Follow-up after Hospitalization for Mental Illness. Agency for Healthcare Research and Quality, US Department of Health \& Human Services, USA.

8. (2014) National Quality Measures Clearinghouse. Measure Summary: 30-Day Follow-up after Hospitalization for Mental Illness. Agency for

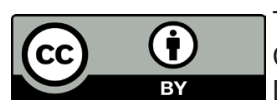

This work is licensed under Creative

Commons Attribution 4.0 Licens

DOI:10.19080/JOJPH.2018.03.555603
Healthcare Research and Quality, Department of Health \& Human Services.

9. (1997) American Academy of Child and Adolescent Psychiatry, American Psychiatric Association. Criteria for Short-Term Treatment of Acute Psychiatric Illness. National Committee for Quality Assurance, USA.

10. (2014) HEDIS 2015: Healthcare Effectiveness Data and Information. National Committee for Quality Assurance, Washington, USA.

11. (2016) The State of Health Care Quality 2015 National Committee for Quality Assurance. Management Strategies to Reduce Psychiatric Readmissions.

12. (2014) Agency for Healthcare Research and Quality, US Department of Health \& Human Services.

13. EA Nelson, ME Maruish, JL Axler (2000) Effects of Discharge Planning and Compliance with Outpatient Appointments on Readmission Rates. Psychiatric Services 51(7): 885-889.

14. (2009) National Committee for Quality Assurance, Follow-Up after Hospitalization for Mental Illness.

15. (2018) Agency for Healthcare Research and Quality Data Warehouse: Shortage Areas. Agency for Healthcare Research and Quality, US Department of Health \& Human Services.

16. (2016) Shortage Designation: Health Professional Shortage Areas \& Medically Underserved Areas/Populations. Agency for Healthcare Research and Quality, US Department of Health \& Human Services.

17. B Japsen (2015) Psychiatrist Shortage Worsens Amid 'Mental Health Crisis'.

18. L Radnofsk (2015) Where Are the Mental-Health Providers? The Wall Street Journal.

19. SL Decker (2012) In 2011 Nearly One-Third Of Physicians Said They Would Not Accept New Medicaid Patients, But Rising Fees May Help. Health Affairs 31(8): 1673-1679.

20. LH Reich, BM Jaramillo, LJ Kaplan, J Arciniega, AD Kolbasovsky (2003) Improving Continuity of Care: Success of a Behavioral Health Program. Journal for Healthcare Quality 25(6): 4-8.

21. (2015) Florida's Agency for Health Care Administration. Model Contract: Exhibit II-A - Managed Medical Assistance Program.

22. (2015) Florida's Agency for Health Care Administration. Model Contract: Exhibit II-C - Serious Mental Illness (SMI).

23. BD Stein, JN Kogan, MJ Sorbero, W Thompson, SL Hutchinson (2007) Predictors of Timely Follow-Up Care among Medicaid-Enrolled Adults after Psychiatric Hospitalization. Psychiatric Services 58(12): 15631569.

\section{Your next submission with Juniper Publishers will reach you the below assets}

- Quality Editorial service

- Swift Peer Review

- Reprints availability

- E-prints Service

- Manuscript Podcast for convenient understanding

- Global attainment for your research

- Manuscript accessibility in different formats

( Pdf, E-pub, Full Text, Audio)

- Unceasing customer service

Track the below URL for one-step submission https://juniperpublishers.com/online-submission.php 